\title{
Assignment of Facultatively Alkaliphilic Bacillus sp. Strain C-125 to Bacillus lentus Group 3
}

\author{
RIKIZO AONO* \\ Department of Bioengineering, Faculty of Bioscience and Biotechnology, \\ Tokyo Institute of Technology, Nagatsuta 4259, \\ Yokohama, 226, Japan
}

\begin{abstract}
Facultatively alkaliphilic Bacillus sp. strain C-125 grew at temperatures of more than $50^{\circ} \mathrm{C}$, did not reduce nitrate to nitrite, and did not deaminate phenylalanine. The guanine-plus-cytosine content of the chromosomal DNA of this organism was 42 mol\%. These characteristics indicate that strain C-125 is related to Bacillus lentus group 3.
\end{abstract}

A large number of alkaliphilic Bacillus spp. strains have been isolated. Most of these strains have been surveyed for production of extracellular enzymes that are stable over a broad $\mathrm{pH}$ range and active at alkaline $\mathrm{pH}$ values ranging from 10 to 12 . Because of their stability and suitability for industrial applications, enzymes produced by alkaliphiles have interested applied enzymologists $(20,21)$. Alkaliphiles are extremophiles that can grow at $\mathrm{pH} 10$ or higher. A few Bacillus strains have been investigated as model systems for understanding the mechanisms of alkaliphily and alkali tolerance. One such organism is Bacillus sp. strain C-125, a facultative alkaliphilic strain. This organism is assigned to the genus Bacillus because of its gram-positive staining characteristics and possible aerobic sporulation (22). The cell wall structures of this organism have been studied extensively $(1,2,12)$. Strain C-125 might adapt to alkaline environments by altering its cell surface $(4,6$, $7,10)$. It is very important that gene manipulation and cell fusion systems be established in this organism $(3,7,8)$. The bioenergetics of the alkaliphilic organisms Bacillus firmus RAB and OF4 has been studied previously $(17,18)$. Determining the taxonomic position of strain C-125 is essential for comparing data obtained with other alkaliphilic Bacillus strains.

Strain C-125 was grown primarily at $37^{\circ} \mathrm{C}$ in an alkaline complex medium ( $\mathrm{pH} 10$ ) containing $0.1 \mathrm{M} \mathrm{Na}_{2} \mathrm{CO}_{3}$ (4), unless specified otherwise. The same medium containing $0.2 \mathrm{M} \mathrm{NaCl}$ instead of $\mathrm{Na}_{2} \mathrm{CO}_{3}$ was adjusted to $\mathrm{pH} 7.2$ (4). This medium was adjusted to a variety of $\mathrm{pH}$ values with $\mathrm{Na}_{2} \mathrm{CO}_{3}$ and $\mathrm{NaOH}$ (9) for observing the morphological characteristics of strain C- 125 cells. If necessary, the media were solidified with $1.5 \%$ (wt/vol) agar.

Morphological characteristics of strain C-125 were determined by conventional methods (13) by using cells grown at different constant $\mathrm{pH}$ values in $\mathrm{pH}$-stat cultures. The morphology of strain $\mathrm{C}-125$ varied with the culture $\mathrm{pH}$, the cultivation temperature, and the growth phase. The cells grew singly and in pairs at $37^{\circ} \mathrm{C}$ and $\mathrm{pH} 7.5$ to 10 (Fig. 1B and C). A few cells formed long chains during the exponential phase of growth. The organism grew in filaments at pH 6.8 and 10.8 (Fig. 1A and D). These $\mathrm{pH}$ values were close to the lower and upper $\mathrm{pH}$ limits for growth. Most filaments were coiled at $\mathrm{pH} 6.8$ and straight at $\mathrm{pH} 10.8$ (Fig. 1A and $\mathrm{D}$ ); this coiling was more pronounced at $30^{\circ} \mathrm{C}$ than at $37^{\circ} \mathrm{C}$ (data not shown). Most cells grown at $\mathrm{pH} 7.0$ to 7.5 formed coiled filaments at $30^{\circ} \mathrm{C}$. Old cultures contained many long chains and filaments; extremely long filaments were formed at $\mathrm{pH} 10.8$ (Fig. $1 \mathrm{E}$ to $\mathrm{H}$ ). The rate of cross-linking among peptide moieties of peptidoglycans de-

\footnotetext{
* Fax: (81) 45-924-5819.
}

pends on the culture pH (11); low cross-linking rates might be one explanation for coil formation at $\mathrm{pH}$ 7. The cell dimensions depended on the culture $\mathrm{pH}$. Cells grown at lower $\mathrm{pH}$ values were shorter and wider than cells grown at higher $\mathrm{pH}$ values. Cells grown at $\mathrm{pH}$ values greater than 8 were straight rods with round ends, and cells grown at $\mathrm{pH} 6.8$ appeared to be coccobacillary (Table 1 ).

The motility of cells was determined by the hanging drop method. Flagella were observed microscopically by using cells stained with ammoniacal $\mathrm{AgNO}_{3}$ after treatment with tannic acid (9) and electron microscopically by using cells that had been negatively stained. The cells had numerous peritrichous flagella and were actively motile when they were grown at an alkaline $\mathrm{pH}$. Flagellin synthesis depends on the culture $\mathrm{pH}(9)$. Most cells grown at $\mathrm{pH}$ values below 7 had no flagella or a few short flagella. Sporulation frequency was somewhat dependent on $\mathrm{pH}$. Strain C-125 sporulated abundantly at $\mathrm{pH} 7$ to 9 , but less effectively at $\mathrm{pH}$ values above 10 .

Strain C-125 formed circular, convex, entire, smooth, creamwhite colonies on the neutral (pH 7.2) agar. Initially the colonies were circular, raised, entire, rough, and cream-white on the alkaline $(\mathrm{pH} 10)$ agar; these colonies gradually became irregular and undulate. The colonies were butyrous on each type of agar. No water-soluble pigment was formed around the colonies. Thus, colonial appearance varied depending on the $\mathrm{pH}$ of the agar medium. The variable appearance was probably due to differences in the amounts of cell wall components at different culture $\mathrm{pH}$ values $(1,4)$.

Strain C-125 grew at relatively high temperatures (up to $53^{\circ} \mathrm{C}$ at $\mathrm{pH} 7$ and up to $57^{\circ} \mathrm{C}$ at $\left.\mathrm{pH} 10\right)$ (Table 1). Interestingly, this organism did not grow as well at $\mathrm{pH} 7$ as it did at $\mathrm{pH} 10$ at low temperatures; the minimum temperatures for growth were $20^{\circ} \mathrm{C}$ at $\mathrm{pH} 10$ and $30^{\circ} \mathrm{C}$ at $\mathrm{pH} 7$ when growth was observed after incubation for 5 days. The effect of $\mathrm{pH}$ on growth was determined in $\mathrm{pH}$-stat cultures by using the complex medium and a variety of $\mathrm{pH}$ values at $37^{\circ} \mathrm{C}$. The doubling times of the organism grown in pH-stat cultures were about $1,0.5$, and $2 \mathrm{~h}$ at pH 6.8,9.0, and 10.8, respectively. Strain C-125 grew in the presence of $10 \%$ (wt/vol) $\mathrm{NaCl}$ in the neutral medium containing $0.1 \% \mathrm{KH}_{2} \mathrm{PO}_{4}$ (initial $\mathrm{pH}, 8$ ).

Vitamin requirement, nitrate assimilation, and carbon compound utilization tests were performed by using an alkaline synthetic basal medium. The alkaline synthetic medium $(\mathrm{pH}$ 10) used previously $(4,10)$ was modified so that it contained (per liter of deionized water) $13.7 \mathrm{~g}$ of $\mathrm{K}_{2} \mathrm{HPO}_{4}, 5.9 \mathrm{~g}$ of $\mathrm{KH}_{2} \mathrm{PO}_{4}, 10.6 \mathrm{~g}$ of $\mathrm{Na}_{2} \mathrm{CO}_{3}, 0.05 \mathrm{~g}$ of nitrilotriacetic acid, 0.05 $\mathrm{g}$ of $\mathrm{MgSO}_{4} \cdot 7 \mathrm{H}_{2} \mathrm{O}, 5 \mathrm{~g}$ of glucose, $1 \mathrm{~g}$ of $\left(\mathrm{NH}_{4}\right)_{2} \mathrm{SO}_{4}$, and $1 \mathrm{~g}$ of $\mathrm{KNO}_{3}$. The carbon and nitrogen sources were varied in each test. Other cultural characteristics were determined by stan- 

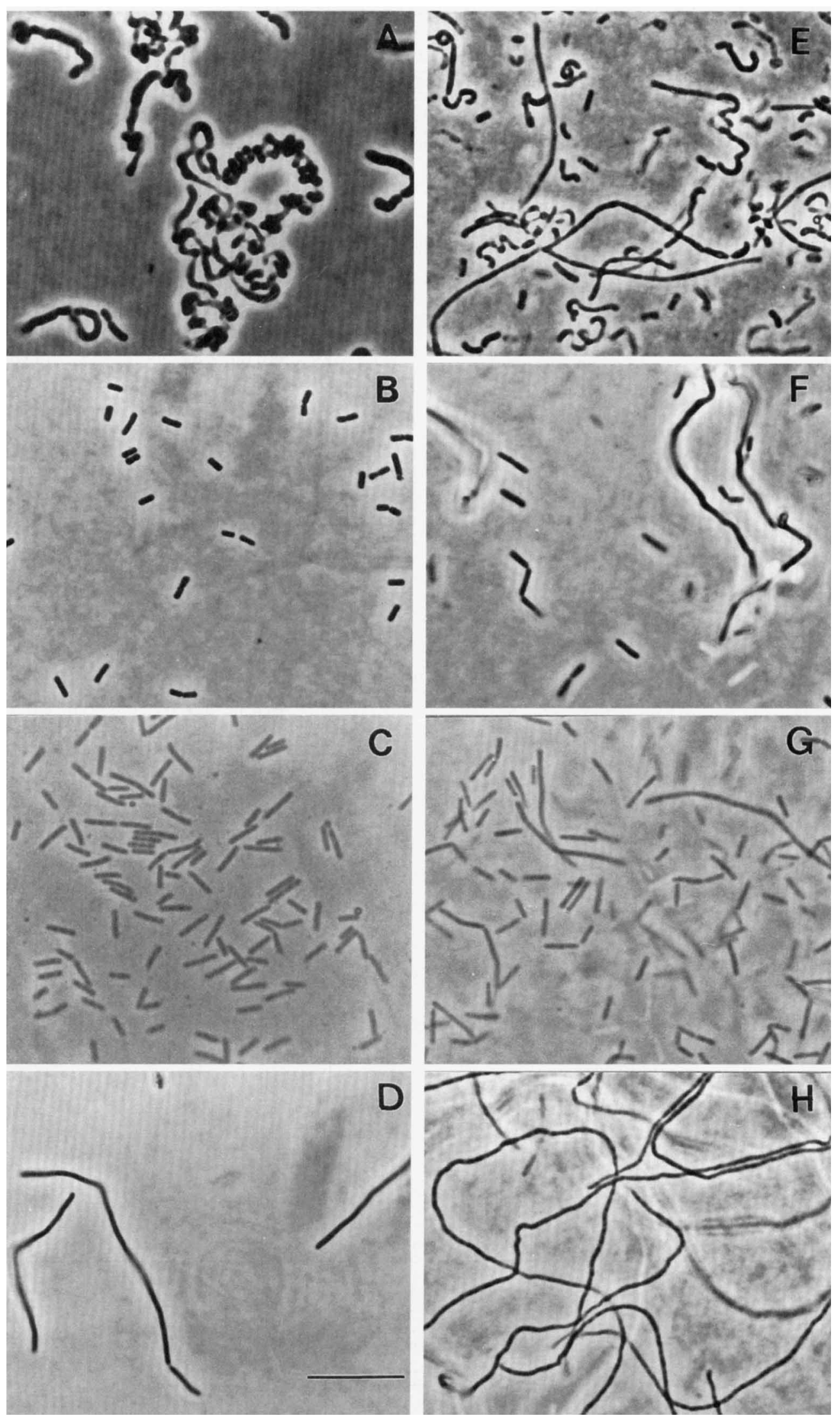

FIG. 1. Cellular morphology of strain C-125. Alkaliphilic Bacillus sp. strain C-125 was grown aerobically in the complex medium at $37^{\circ} \mathrm{C}$, and cellular morphology was observed at the late exponential phase (A to D) or stationary phase $(30 \mathrm{~h})(\mathrm{E}$ to $\mathrm{H})$ of growth. The culture $\mathrm{pH}$ was kept maintained at $\mathrm{pH} 6.8(\mathrm{~A}$ and $\mathrm{E})$, $\mathrm{pH} 7.5$ (B and F), pH 9.0 (C and $\mathrm{G}$ ), or $\mathrm{pH} 10.8$ (D and H). The same magnification was used for all micrographs. Bar $=10 \mu \mathrm{m}$. 
TABLE 1. Characteristics of alkaliphilic Bacillus sp. strain C-125a

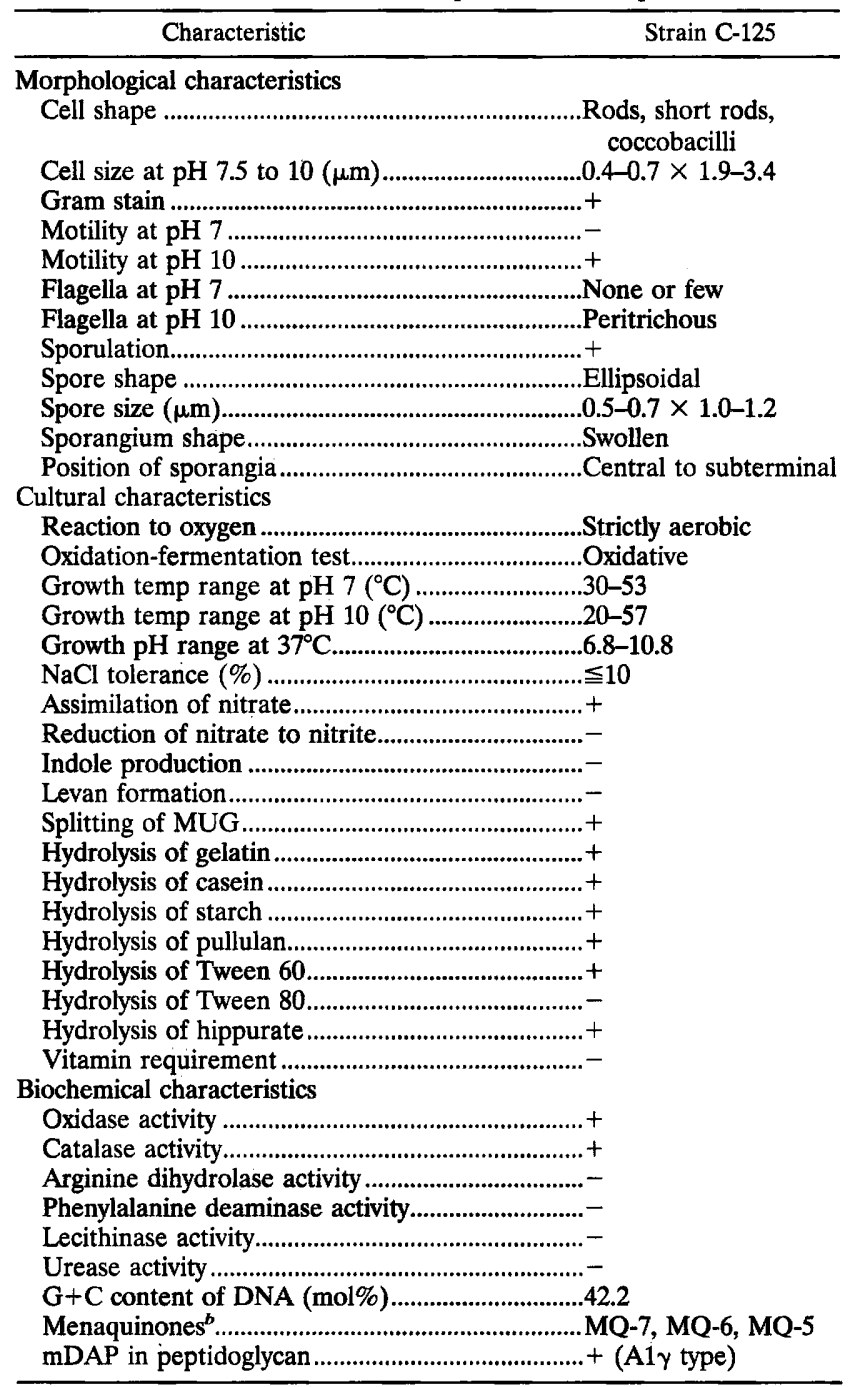

${ }^{a}+$, positive; -, negative; MUG, 4-methyl-umbelliferyl- $\beta$-D-glucuronide; MQ, menaquinone; mDAP, meso-diaminopimelic acid.

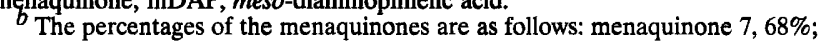
menaquinone $6,25 \%$; menaquinone $5,7 \%$. dard methods (25). Strain C-125 grew by assimilating nitrate instead of ammonium ions, but did not exhibit anaerobic denitrification. This organism was strictly aerobic and positive for oxidase and catalase activities. The enzyme activities listed in Table 1 were determined by standard methods (25). The carbon sources assimilated by the organism included several pentoses, hexoses, hexitol, and oligosaccharides (Table 2).

The chromosomal DNA of strain C-125 was digested with nuclease P1 (26). The resulting nucleotides were separated by high-performance liquid chromatography by using a Cosmosil $5 \mathrm{C}_{18}$ column ( 4.6 by $150 \mathrm{~mm}$; Nakalai Tesque, Kyoto, Japan) that was eluted with $10 \mathrm{mM} \mathrm{KH}_{2} \mathrm{PO}_{4}-\mathrm{NaOH}$ buffer (pH 7.0) at a flow rate of $1 \mathrm{ml} / \mathrm{min}$. The $\mathrm{G}+\mathrm{C}$ content of the chromosomal DNA was $42 \mathrm{~mol} \%$.

Cells grown in the alkaline complex medium were extracted twice with methanol-chloroform $(1: 2, \mathrm{vol} / \mathrm{vol})$. The resulting extracts were washed with water and concentrated to dryness in a rotary evaporator. The acetone-soluble apolar lipids were obtained from the residue and resolved on a silica gel thin layer in $n$-hexane-diethylether $(4: 1, \mathrm{vol} / \mathrm{vol})$. Yellow compounds with an $R_{f}$ value corresponding to the $R_{f}$ value of menaquinone prepared from Bacillus subtilis GSY1026 (4) were recovered and applied to a reverse-phase column (ODS-H-1251; 4.6 by $250 \mathrm{~mm}$; Senshu Science, Tokyo, Japan), and the column was eluted with an acetonitrile-isopropanol mixture (23). The isoprenoid quinones were detected by measuring $A_{270}$. The quinone was measured by using menadione as a standard. The menaquinone system of the organism was similar to that found in $B$. subtilis. No ubiquinone-like pigment was found in the lipid fraction. The isoprene side chains of the quinone ranged from five to seven isoprene units long. The predominant quinone was menaquinone 7 . The quinone composition depended to some extent on the culture $\mathrm{pH}$ (data not shown).

Peptidoglycan was prepared from strain C-125 as described previously (5). The isomerism of the diaminopimelic acid was determined by thin-layer chromatography (19) of peptidoglycan hydrolysates $\left(4 \mathrm{M} \mathrm{HCl}, 105^{\circ} \mathrm{C}, 15 \mathrm{~h}\right)$. The peptidoglycan type of strain C-125 was type A1 $\gamma$. The $\gamma$-carboxyl group of L-glutamic acid or the $\omega$-carboxyl group of meso-diaminopimelic acid was not amidated. The glycan chain was composed of $N$-acetylglucosamine and $N$-acetylmuramic acid (4). This subtype of type A1 $\gamma$ peptidoglycan is found in the cell

TABLE 2. Comparison of the properties of strain C-125 and B. firmus-B. lentus intermediates

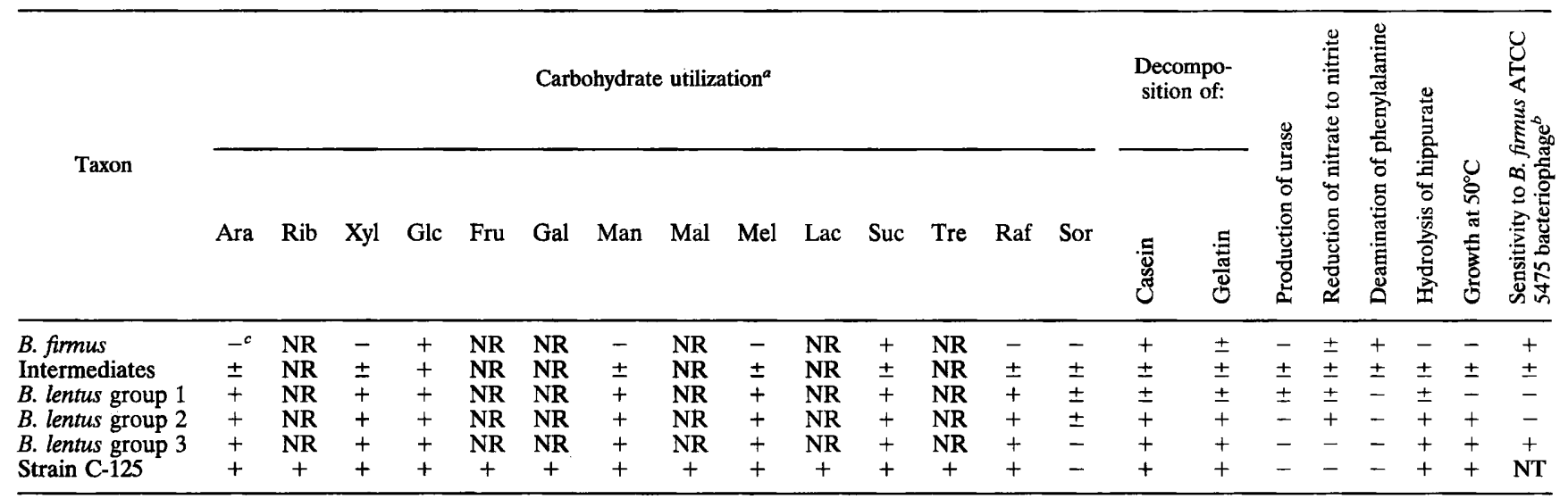

a Abbreviations: Ara, L-arabinose; Rib, D-ribose; Xyl, D-xylose; Glc, D-glucose; Man, D-mannose; Mal, maltose; Mel, melibiose; Lac, lactose; Suc, sucrose; Tre trehalose; Raf, raffinose; Sor, sorbitol. The utilization of carbohydrates by strain C-125 was determined in this study; the utilization of carbohydrates by other strains was determined by examining acid production from carbohydrates in another study (15).

See reference 15

$c_{+}$, strains are positive; - , strains are negative; \pm , some strains are positive and some strains are negative; NR, not reported; NT, not tested. 
TABLE 3. Comparison of the properties of strain C- 125 and the six groups classified by Fritze et al. ${ }^{a}$

\begin{tabular}{lclccc}
\hline Taxon & $\begin{array}{c}\text { G+C } \\
\text { content } \\
(\mathrm{mol} \%)\end{array}$ & $\begin{array}{c}\text { Colony } \\
\text { color }\end{array}$ & $\begin{array}{c}\text { Growth } \\
\text { at 50 }\end{array}$ & $\begin{array}{c}\text { Deamination } \\
\text { of phenyl- } \\
\text { alanine }\end{array}$ & $\begin{array}{c}\text { Reduction } \\
\text { of nitrate }\end{array}$ \\
\hline Group 1 & $38.2-40.8$ & Bright yellow & - & + & - \\
Group 2 & $38.2-40.8$ & Dull yellow & - & - & - \\
Group 3 & $42.1-43.9$ & Cream-white & + & - & + \\
Group 4 & $42.1-43.9$ & Cream-white & + & - & - \\
Group 5 & $34.0-37.5$ & Cream-white & - & - & - \\
Group 6 & $34.0-37.5$ & Cream-white & - & - & + \\
Strain C-125 & 42.2 & Cream-white & + & - & - \\
\hline
\end{tabular}

${ }^{a}$ The properties of strain $\mathrm{C}-125$ were determined in this study, and the data for the other taxa were obtained from reference 14.

walls of B. firmus, Bacillus lentus, and Bacillus megaterium, but not in the cell walls of Bacillus licheniformis or B. subtilis (24).

Several other alkaliphilic Bacillus spp. strains also grow at pH 7 (4). Gordon and Hyde investigated variants capable of growth at $\mathrm{pH} 7.0$ that were obtained from 174 alkaliphilic Bacillus strains (15). These organisms were assigned to five subgroups of the $B$. firmus-B. lentus complex on the basis of their physiological characteristics. The characteristics of neutrophilic strains of $B$. firmus and B. lentus are very diverse (16). The characteristics of the $\mathrm{pH} 7.0$ variants obtained from the alkaliphilic strains are also very diverse. The variants designated $B$. lentus were further subdivided into three groups on the basis of growth at $50^{\circ} \mathrm{C}$, sensitivity to some bacteriophages, and reduction of nitrate to nitrite, as shown in Table 2 .

Alkaliphilic Bacillus sp. strain C-125 grew at $57^{\circ} \mathrm{C}$ on the alkaline agar and at $53^{\circ} \mathrm{C}$ on the neutral agar. Nitrate was not reduced to nitrite by strain $C-125$. These properties are consistent with the properties of $B$. lentus group 3. Strain C-125 is not related to $B$. firmus. The cellular morphology of $B$. lentus group 3 as described by Gordon and Hyde was similar to the morphology of strain $\mathrm{C}-125$ grown at $37^{\circ} \mathrm{C}$ and $\mathrm{pH} 7.5$ to 10 . The spore and sporangium characteristics of $B$. lentus group 3 were also the same as those of strain $\mathrm{C}-125$ at $\mathrm{pH} 7$ to 9 . The other properties of $B$. lentus group 3 were also consistent with those of strain C-125, as shown in Table 2. Therefore, strain $\mathrm{C}-125$ is most similar to $B$. lentus group 3 .

The DNA base compositions of several alkaliphilic Bacillus spp. strains have been determined by the buoyant density centrifugation method (14) or by chemical analysis of nucleosides released enzymatically from DNA (26). A wide range of DNA base compositions has been found in the alkaliphiles. The alkaliphilic Bacillus strains have been arbitrarily divided into three groups on the basis of their DNA G+C contents as follows: group A, 34.0 to 37.5 mol\%; group B, 38.2 to 40.8 mol\%; and group C, 42.1 to 43.9 mol\% (14). Each group has been further subdivided into two phenotypic groups, as shown in Table 3. Table 3 also shows the properties that were used to classify the six phenotypic groups. The $\mathrm{G}+\mathrm{C}$ content of strain $\mathrm{C}-125$ is the same as the $\mathrm{G}+\mathrm{C}$ contents of members of groups 3 and 4 proposed by Fritze et al. (14). The colony color and other phenotypic characteristics of strain C-125 indicated that this organism belongs to group 4 . This group contains all but one strain of $B$. lentus group 3 of Gordon and Hyde $(14,15)$. My observations indicated that strain $\mathrm{C}-125$ is related to $B$. lentus group 3 of Gordon and Hyde.

This work was supported in part by a grant for the "Biodesign Research Program" from RIKEN to R. Aono.
I thank M. Yamamoto, M. Ogino, and H. Kaneko for assistance, and I am indebted to K. Horikoshi for earnest discussions.

\section{REFERENCES}

1. Aono, R. 1985. Isolation and partial characterization of structural components of the walls of alkalophilic Bacillus strain C-125. J. Gen. Microbiol. 131:102-111.

2. Aono, R. 1989. Characterization of cell wall components of the alkalophilic Bacillus strain C-125: identification of a polymer composed of polyglutamate and polyglucuronate. J. Gen. Microbiol. 135:265-271.

3. Aono, R., M. Hashimoto, A. Hayakawa, S. Nakamura, and K. Horikoshi. 1992. A novel gene required for the alkaliphily of the facultative alkaliphile Bacillus sp. strain C-125. Biosci. Biotech. Biochem. 56:842-844.

4. Aono, R., and K. Horikoshi. 1983. Chemical composition of cell walls of alkalophilic strains of Bacillus. J. Gen. Microbiol. 129:1083-1087.

5. Aono, R., K. Horikoshi, and S. Goto. 1984. Composition of the peptidoglycan of alkalophilic Bacillus spp. J. Bacteriol. 157:688-689.

6. Aono, R., M. Ito, and K. Horikoshi. 1992. Instability of the protoplast membrane of facultative alkaliphilic Bacillus sp. C-125 at alkaline $\mathrm{pH}$ values below the pH optimum for growth. Biochem. J. 285:99-103.

7. Aono, R., M. Ito, and K. Horikoshi. 1993. Regeneration of protoplasts prepared from alkaliphilic strains of Bacillus spp. Biosci. Biotech. Biochem. 57:1597-1598.

8. Aono, R., M. Ito, K. Joblin, and K. Horikoshi. 1994. Genetic recombination after cell-fusion of protoplasts from the facultative alkaliphile Bacillus sp. C-125. Microbiology (London) 140:3085-3090.

9. Aono, R., H. Ogino, and K. Horikoshi. 1992. pH-dependent flagella formation by facultative alkaliphilic Bacillus sp. C-125. Biosci. Biotech. Biochem. 56:48-83.

10. Aono, R., and M. Ohtani. 1990. Loss of alkalophily in cell-wall-componentdefective mutants derived from alkalophilic Bacillus C-125: isolation and partial characterization of the mutants. Biochem. J. 266:933-936.

11. Aono, R., and T. Sanada. 1994. Hyper-autolysis of the facultative alkaliphile Bacillus sp. C-125 cells grown at neutral $\mathrm{pH}$ : culture-pH dependent crosslinking of the peptide moieties of the peptidoglycan. Biosci. Biotech. Biochem. 58:1231-1235.

12. Aono, R., and M. Uramoto. 1986. Presence of fucosamine in teichuronic acid of the alkalophilic Bacillus strain C-125. Biochem. J. 233:291-294.

13. Doetsch, R. N. 1981. Determinative methods of light microscopy, p. 21-33. In P. Gerhardt, R. G. E. Murray, R. N. Costilow, E. W. Nester, W. A. Wood, N. R. Krieg, and G. B. Phillips (ed.), Manual of methods for general bacteriology. American Society for Microbiology, Washington, D.C.

14. Fritze, D., J. Flossodorf, and D. Claus. 1990. Taxonomy of alkaliphilic Bacillus strains. Int. J. Syst. Bacteriol. 40:92-97.

15. Gordon, R. E., and J. L. Hyde. 1982. The Bacillus firmus-Bacillus lentus complex and $\mathrm{pH} 7.0$ variants of some alkalophilic strains. J. Gen. Microbiol. 128:1109-1116.

16. Gordon, R. E., J. L. Hyde, and J. A. Moore, Jr. 1977. Bacillus firmus-Bacillus lentus: a series or one species? Int. J. Syst. Bacteriol. 27:256-262.

17. Guffanti, A. A., R. Blanco, R. A. Benenson, and T. A. Krulwich. 1980. Bioenergetic properties of alkaline-tolerant and alkalophilic strains of $B a$ cillus firmus. J. Gen. Microbiol. 119:79-86.

18. Guffanti, A. A., O. Finkelthal, D. B. Hicks, L. Falk, A. Sidhu, A. Garro, and T. A. Krulwich. 1986. Isolation and characterization of new facultatively alkalophilic strains of Bacillus species. J. Bacteriol. 167:766-773.

19. Hoare, D. S., and E. Work. 1957. The stereoisomers of $\alpha, \varepsilon$-diaminopimelic acid. Biochem. J. 65:441-447.

20. Horikoshi, K. 1971. Production of alkaline enzymes by alkalophilic microorganisms. I. Alkaline protease produced by Bacillus No. 221. Agric. Biol. Chem. 35:1407-1414.

21. Horikoshi, K. (ed.) 1991. Microorganisms in alkaline environments, p. 187-246. VCH Publishers, New York.

22. Ikura, Y., and K. Horikoshi. 1979. Isolation and some properties of $\beta$-galactosidase producing bacteria. Agric. Biol. Chem. 43:85-88.

23. Kroppenstedt, R. M. 1985 . Fatty acid and menaquinone analysis of actinomycetes and related organisms, p. 173-199. In M. Goodfellow and D. E. Minnikin (ed.), Chemical methods in bacterial systematics. Academic Press, New York.

24. Schleifer, K. H., and O. Kandler. 1972. Peptidoglycan types of bacterial cell walls and their taxonomic implications. Bacteriol. Rev. 36:407-477.

25. Smibert, R. M., and N. R. Krieg. 1981. General characterization, p. 404-443. In P. Gerhardt, R. G. E. Murray, R. N. Costilow, E. W. Nester, W. A. Wood, N. R. Krieg, and G. B. Phillips (ed.), Manual of methods for general bacteriology. American Society for Microbiology, Washington, D.C.

26. Tamaoka, J., and K. Komagata. 1984. Determination of base composition by reversed-phase high-performance liquid chromatography. FEMS Microbiol. Lett. 25:125-128. 